\title{
Over the Im/permeable Boundaries: Cinematization of Nianchan in South Korea and Japan
}

So Hye Kim*

Nianchan ${ }^{1}$, literally meaning "my second eldest brother," is a journal of an orphaned second-generation zainichi girl, Yasumoto Sueko. It was first published in 1958 in Japan and became a best seller for two years. Describing Sueko and her siblings' daily struggles against grinding poverty which is about to separate them, it was "read as something like the Japanese equivalent of Anne Frank's diary." Although it drew the largest Japanese readership in postwar Japan among the books written by a zainichi Korean, it has barely been discussed either as zainichi literature or as postwar popular Japanese literature.

Another notable but underexplored aspect of this book is that it was a rare example of a cultural product that managed to cross the border between South Korea and Japan in the late 50s and enjoyed popular attention in both countries. Within three months after the Japanese publish date, Korean translations were published under two different titles. ${ }^{3}$ In 1959,

* $\mathrm{PhD}$ Candidate, Department of East Asian Languages and Civilizations, University of Chicago

1 Sueko Yasumoto, Nianchan, jussai no shojo no nikki [My second brother: 10-yearold girl's journal] (Tokyo: Kōbunsha, 1958).

2 John Lie, Zainichi (Koreans in Japan): Diasporic Nationalism and Postcolonial Identity (Berkeley: University of California Press, 2008), 12-13.

3 Sueko Yasumoto, Sib se chaeil Han'guk sonyŏ ŭi sugi [A journal of 10-year-old Korean girl in Japan] (Seoul: Taedong Munhwasa, 1959); Sueko Yasumoto, 
Nianchan was adapted into films by two noted directors, Imamura Shōhei in Japan and Yu Hyŏn-mok in South Korea, respectively. Under the South Korean government's rigorous censorship of any representation of contemporary Japan, how could this story have been introduced to Korean readers and audiences? What kind of modifications were at play during this cultural border crossing? By examining the process of the cultural transmission and film adaptation of Nianchan, this review discusses the im/permeability of cultural borders between the two countries, partly occasioned by Rhee Syngman regime's ban on Japanese popular culture and the intertwined relationship between the process of making national culture and that of situating Korean diaspora on either side of these $\mathrm{im} /$ permeable borders.

Nianchan, the original journal, its publication, and its film adaptation were all produced against the backdrop of rapidly changing relations between South Korea, North Korea, and Japan. Yasumoto Sueko's journal covers the period between January 1953 and September 1954; given that the armistice was signed in July 1953, this period briefly overlaps with the Korean War. Furthermore, around the time when the journal was published and made into films, there were heightened tensions between South Korea, North Korea, and Japan over the issue of the zainichi Korean's repatriation to North Korea. This repatriation effort brought about by the intermediary work of the Red Cross in 1958-59, and was met with vehement opposition from the South Korean government.

When two different versions of Korean translation of the journal in question were published without author's permission in early 1959, Kōbunsha, the original publisher in Japan, as well as the author, criticized the pirated editions in Korea, citing many instances of mistranslation. ${ }^{4}$ However, the issue of writer's copyrights suddenly shifted to suspicion of

Kurüm ŭn hŭlŏdo [Even if the clouds are drifting], trans. Yu Chu-hyŏn (Seoul: Sint'aeyangsa, 1959).

4 "Munje doen Han'guk sonyŏ ŭi sugi [Korean girl's journal, beset with problems]," Kyŏnghyang Sinmun, January 26, 1959. 
Yasumoto's identity, ideology, and citizenship. For example, South Korea's Ministry of Education announced its immediate answer as follows.

As the Republic of Korea has not yet signed the International Copyright Treaty, the Korean publishers are not legally obliged to get permission from the author abroad. Thus, the Korean publication of Nianchan is not against Korean national law. However, to publish a translated edition of a Japanese publication, the publisher should attain permission from the Korean government, and the Korean publisher of Nianchan has not yet fulfilled this obligation. In addition to that, to investigate whether the author, Yasumoto Sueko, is affiliated with Choryŏn ${ }^{5}$ [sic], we asked the Ministry of Home Affairs to conduct a background check on her. ${ }^{6}$

As this statement shows, the ROK government was not interested in the violated rights of Yasumoto. Far from it, but it only focused on whether this publication violated government regulations restricting Japanese cultural products and whether or not Yasumoto was an ideologically 'dangerous' person. In other words, what was more important for the Korean government regarding the issue of Nianchan was whether Yasumoto's visibility would violate two foundations of the Rhee regime: antiJapanese (panil) and anti-communism (pan'gong).

The copyright issues of Nianchan were resolved in an unexpected way. A week after the Japanese publisher's complaint was reported in Korea, An Tong-bok, Yasumoto Sueko's second cousin living in Posŏng city of Chŏlla province, sent a genealogy document and a letter to the Yasumoto

5 Choryŏn (Chōren in Japanese, the League of Koreans in Japan) was forced to dissolve in 1949 and Ch'ongryŏn (Sōren in Japanese, The General Association of Korean Residents in Japan) was established in 1955. Thus, even though it is written as "Choryŏn" in this article, the correct designation ought to be "Ch'ongryŏn."

6 "Il sŏ mudan ch'ulgan dŭng e pun'gyŏk [The author in Japan, infuriated by the publication without permission]," Tong-a ilbo, January 26, 1959. 
siblings to the Kyŏnghyang newspaper company. The Korean media reported subsequent correspondence between the Yasumoto family and An Tong-bok and finally published an article about the author entrusting all copyrights of Nianchan in South Korea to this second cousin, with a photograph of Yasumoto Sueko's own writing attesting to this arrangement. ${ }^{7}$

The copyright issue of Nianchan in Korea acutely demonstrates the intricate configuration of ethnicity, nationality, and ideology surrounding the zainichi identity in the transition period from the colonial to the Cold War era. South Korean publishers argued that they were convinced that this book should be introduced to Korean readers as it is "our tongp' $o$ 's (compatriot) writing." The term tongp'o, literally meaning "same uterus," underlines ethnonational homogeneity of Korean people. As Theodore Hughes noted, the term has been "frequently invoked as a nonideological site for overcoming national division" ever, when the tongp'o author claimed her rights to the publication, South Korean media and government requested Yasumoto Sueko to identify her nationality and her ideological inclination between the DPRK and the ROK. In the end, after these interrogations, all copyrights for Nianchan in South Korea were handed over to her second cousin, whom she had never met before. The patriarchal family system eventually took over this zain$i c h i$ writer's copyrights in the homeland.

Right after the Korean translation of Nianchan was published, a domestic cinematic adaptation was prepared under the title, Even the Clouds Are Drifting, as the seventh feature film by the director Yu Hyŏn-mok. ${ }^{9}$

7 "Yukch'on oppa e wi'im [Enthrusting to the second cousin]," Tong-a ilbo, March $31,1959$.

8 Theodore Hughes. Literature and Film in Cold War South Korea: Freedom's Frontier (New York: Columbia University Press, 2012), 149.

9 Kim Sŭng-gu points the close affinity between the film adaptation of Nianchan and the colonial popularity of films based on children's writing, such as Suöpryo [Tuition] (directed by Ch'oe In-gyu, 1940), Tsuzurikata kyōshitsu [Composition Class] (directed by Yamamoto Kajirō, 1938). See Sŭng-gu Kim, “Adong changmun ŭi yŏnghwahwa wa Han Il munhwa kyosŏp,'[Filmmaking based on children's writ- 
However, there was a big obstacle he had to overcome to complete this film: the governmental censorship under the Syngman Rhee regime. One stringent criterion of the Rhee regime's censorship was its anti-Japanese policy. Japan and its colonial past had often been cinematized under the Rhee regime albeit only to depict fierce independence movements, yet representation of contemporary postwar Japan was taboo in this same period. Any form of popular culture from Japan, including popular music, comics, and films, had been officially banned from importation into South Korea from the time of the Rhee regime until the lifting of ban in 1998.

On March $18^{\text {th }}$, 1959, the Domestic Film Advisory Committee concluded that the production of Even the Clouds Are Drifting should not be allowed. The reason was that the context of postwar Japanese society surrounding the Yasumoto family was so essential that it would be impossible to cinematize it without portraying the Japanese setting. Even the best make-up and set dressing could not render the story "realistic" without showing the Japanese setting, the Committee argued. ${ }^{10}$ In response to the government's decision, the film producer decided to change the setting of the film from Irinomura, a mining town in Kyushu, to Yŏngwol, a South Korean town in Kangwon Province, in addition to changing all characters to Koreans. Yasumoto Sueko's writing and its filmic adaptation were therefore situated in a grey zone between animosity against waesaek (Japanese style/culture) and sympathy for tongp'o. The Rhee regime's antiJapanese policy and anti-communism as well as its nationalistic notions about overseas Koreans expected zainichi Koreans to have no Japanese mannerism as well as to be non-Communist, i.e. a sanitized image of compatriots. In this framework, there was no room for zainichi Koreans to speak out and alas, Nianchan, the rare example of the zainichi's selfenunciation, was ruled impermissible in South Korea.

ing and cultural negotiation between Korea and Japan] Han'gukhak Yŏngŭ 41 (2012): 137-161.

10 "Kurŭm ŭn hŭlŏdo yŏnghwahwa pu chŏkdang [Even the Clouds Are Drifting, inappropriate for cinematization]," Chosŏn ilbo, March 19, 1959. 
While Sueko's diary appealed to the feelings shared by a wide readership in Japan and Korea, who had experienced the same type of devastations of war and poverty, it also clearly notes that her ethnic identity as a Korean was the foremost reason for her difficult life. Sueko is aware that Kiichi, her eldest brother could not be hired as a regular worker because he was a Korean, ${ }^{11}$ and also writes the ethnic discrimination she confronts in her daily life. In the entry of June 17th, 1954, while living off a neighbor's beneficence, she writes about how she was despised by the lady: "I heard that the lady says 'Go away, penniless Koreans! Go back to your home! (Binbo tsyosenjin, deteike. Oigata no ieni orasen [sic]!)'” 12 She transcribes the insulting phrase the old lady uttered in romaji (alphabetic rendition), highlighting the feelings of frustration and humiliation she had to endure due to her ethnicity. Nevertheless, this awareness of ethnic discrimination was diluted in the midst of the book's wide reception in Japan. Yim Sang-min notes that, the award-winning compositions for the Kōbunsha-sponsored nationwide book report competition on Nianchan tended to render the correlation between Yasumoto's ethnicity and her poverty less visible. ${ }^{13}$

Then how did the films made in Korea and Japan re-contextualize the Yasumotos' suffering in their films? The opening scene of Even the Clouds Are Drifting epitomizes the general tone of the film. When the film begins, it shows a long shot of the coal-mining town, but in the foreground children are marching and singing. Above the children singing "Na ŭi saldŏn kohyang ŭn [My Hometown]," mine shafts are moving slowly. The town this film describes is not a place under the burden of poverty but a place of growth, just like young children themselves.

However, even in this pastoral town, Mal-suk's (the Korean adaptation

11 Sueko Yasumoto, Nianchan, jussai no shojo no nikki (Tokyo: Kōbunsha, 1958), 12. 12 Ibid., 192.

13 Sangmin Yim, Sengo zainichi Korian hyosho- no hankeifu [Anti-genealogy of postwar representation of zainichi Korean] (Fukuoka-shi: Hana Shoin, 2011), 2332. 
of Sueko's name) eldest brother, Tong-sŏk, is in danger of losing his job, except that this is not due to social discrimination against his ethnicity but his physical weakness. The company decides to fire temporary workers based on the results of physical examinations and gives bonuses to the healthier workers. Tong-sŏk gets fired but he willingly accepts his condition of losing his job because he is not as strong as other people. He does not blame anyone for this, but accepts the company's rather cruel decision to sacrifice weak people for the sake of something greater: development of the town. In other words, the Korean film adaptation switches the reason of Tong-sŏk's unemployment from the ethnic discrimination which traces back to the history of Japanese colonialism, to the bodily matters which exclusively belongs to Tong-sŏk's physical individuality, and furthermore, to noble sacrifice for the sake of higher value.

While Tong-sŏk and Yang-suk, his younger sister, leave town to find jobs, Mal-suk and her second eldest brother are always surrounded by neighbors willing to help Mal-suk's family. Mal-suk's school teacher encourages her to write a daily journal and express her feelings through composition. The mine president's daughter, who used to work at a publishing house, happens to read Mal-suk's journal and sends it to the publisher. Eventually, Mal-suk's journal is published and attracts national attention. Thanks to the popularity of the book, Mal-suk's family gets back together.

One notable thing in this film is its temporal setting. While the original journal was written by Sueko from 1953 to 1954, Even the Clouds Are Drifting is set in 1949, one year before the Korean War. This specific temporal setting might be an understandable choice in order to capture an idyllic and nostalgic image of Mal-suk's life, free from any Korean Warrelated social turbulence. However, this temporal shift casts a shadow over the happiness Mal-suk's family finally achieves at the end of film, making it appear grimly unrealistic or soon to be destroyed, the possibility seemingly and ironically commented on when Mal-suk says to her brother, "Oppa, let's live here for a long, long time!"

Meanwhile, the Japanese film Nianchan foregrounds poverty which not 
only torments the Yasumoto family but rules the whole community. The opening voice-over narration explains the temporal setting as a recession period between the Korean War Boom and the Jinmu Boom, when a number of coal-mining companies went into bankruptcy. A montage of a depressed mining town follows the narration. All the vehicles are stopped and people are lying under the flags of the strike, which creates a stark contrast with the opening scene of Even the Clouds Are Drifting.

The film Nianchan extrapolates the Yasumoto family's financial difficulty to the entire town and renders the main reason for their poverty, which is their Korean ethnicity, rather invisible. Similar to the ways the book Nianchan has been received in Japan, the film turns Sueko's personal story into a universal story of Japanese people in difficult times, appealing to nostalgic sentiments, while gazing back from the rapidly developing economy of 1959.

Unlike Even the Clouds Are Drifting, the narrative of Nianchan focuses on Takaichi, Sueko's brother, more than on Sueko, the nominal protagonist. In an article, director Imamura Shōhei mentioned that he wanted to make a character as "a child full of positive energy (faito no aru kodo$m o) . " 14$ The child with this positive energy, this film foregrounds, is Takaichi, who is never depressed or intimidated by his social surroundings but finds his own way to change his life by himself. When his elder siblings leave him and Sueko, Takaichi does not remain passive but finds a part-time job and even goes to Tokyo to find his own work there. While he ventures forth to improve his own fate, Sueko is left alone writing a journal and shedding tears. By switching the focus of narrative from Sueko to Takaichi, the film envisions an ambitious self-supporting second-generation zainichi child. Imamura's view of the zainichi protagonist is somehow capable of avoiding being entangled in the contemporary diplomatic struggles among South Korea, Japan, and North Korea. Takaichi is not a person who would choose to go to North Korea or to be

14 Shōhei Imamura, "Faito no aru kodomo [Child with full positive energy]," Kinema Junppo, October 15, 1959, 127. 
a burden on the Japanese state by living off welfare, but a person who will manage to live self-sufficiently. Thus, what "a child full of positive energy" really means is an untroublesome zainichi Korean, who will not burden Japan, be ideologically dangerous, or demand accountability for the colonial past.

Between 1945 and the Korean War, the geopolitical borders of South Korea have been redrawn several times. The reestablishment of national frontiers subsequently reconstructed the South Korean cultural realm by redefining what is to be included or excluded within them. The representation of the zainichi in South Korean cinema discloses this process of inclusion and exclusion and the concomitant "boundary making" of national culture. The historical and cultural negotiations over the border crossings of Yasumoto Sueko's Nianchan and the film adaptations in each country illuminate the ways in which postwar amnesia of the colonial past was reinterpreted, reworking and problematizing the relationship between the production of national cinema and the positioning of Korean diaspora in relation to these im/permeable borders.

\section{Films Cited}

1. Yu, Hyŏn-mok. Kurŭm ŭn hŭlŏdo.Yuhan Yŏnghwasa, 1959; 101min; 35mm; From Korean Film Archive, VOD, http://www.kmd b.or.kr/vod/vod_basic.asp?nation=K\&p_dataid=00518\&keyword $=\%$ EA\%B5\%AC\%EB\%A6\%84\%EC\%9D\%80\%20\%ED\%9D\%98\%EB $\% 9 F \% A C \%$ EB\%8F\%84 (Accessed February 8, 2017)

2. Imamura, Shōhei. Nianchan. DVD. Directed by Shōhei Imamura. 1959. [Tokyo]: Geneon Entertainment, 2003. 
